\title{
A Bottom-Up Building Stock Model for Tracking Regional Energy Targets-A Case Study of Kočevje
}

\author{
Marjana Šijanec Zavrl ${ }^{1,2, *}$, Gašper Stegnar ${ }^{1}$, Andraž Rakušček ${ }^{1}$ and Henrik Gjerkeš ${ }^{1,3}$ \\ 1 Building and Civil Engineering Institute ZRMK, Dimičeva 12, 1000 Ljubljana, Slovenia; \\ gasper.stegnar@gi-zrmk.si (G.S.); andraz.rakuscek@gi-zrmk.si (A.R.); henrik.gjerkes@gi-zrmk.si (H.G.) \\ 2 European Faculty of Law, Cankarjevo nabrežje 11, 1000 Ljubljana, Slovenia \\ 3 Centre for Systems and Information Technologies, University of Nova Gorica, Vipavska 13, \\ 5000 Nova Gorica, Slovenia \\ * Correspondence: marjana.sijanec@gi-zrmk.si; Tel.: +386-41-609-818
}

Academic Editor: Joanne Patterson

Received: 30 July 2016; Accepted: 14 September 2016; Published: 21 October 2016

\begin{abstract}
The paper addresses the development of a bottom-up building stock energy model (BuilS) for identification of the building stock renovation potential by considering energy performance of individual buildings through cross-linked data from various public available databases. The model enables integration of various EE and RES measures on the building stock to demonstrate long-term economic and environmental effects of different building stock refurbishment strategies. In the presented case study, the BuilS model was applied in the Kočevje city area and validated using the measured energy consumption of the buildings connected to the city district heating system. Three strategies for improving the building stock in Kočevje towards a more sustainable one are presented with their impact on energy use and $\mathrm{CO}_{2}$ emission projections up to 2030. It is demonstrated that the BuilS bottom-up model enables the setting of a correct baseline regarding energy use of the existing building stock and that such a model is a powerful tool for design and validation of the building stock renovation strategies. It is also shown that the accuracy of the model depends on available information on local resources and local needs, therefore acceleration of the building stock monitoring on the level of each building and continually upgrading of databases with building renovation information is of the utmost importance.
\end{abstract}

Keywords: bottom-up modelling; renovation scenarios; building stock; regional energy policy

\section{Introduction}

Slovenia accepted ambitious targets for renovation of existing buildings described in the national strategic documents. National energy efficiency action plan 2014-2020 (NEEAP) [1], and Long-term strategy for mobilizing investment in the renovation of national buildings stocks (LTS) [2] set the national target to improve energy efficiency (EE) by $20 \%$ by 2020 , in line with the requirements set out in Directive 2012/27/EU (Energy Efficiency Directive). The existing building stock represents the sector with the greatest potential for achieving energy savings. To meet the national EE target, a quarter of that building stock, or around 22 million $\mathrm{m}^{2}$ of useful floor area, has to be renovated in line with the minimum requirements on efficient use of energy defined in the national regulation. The improved energy performance of existing buildings will reduce the energy consumption of the entire building stock by almost $10 \%$ in the period 2014-2020.

On the other side, many EU municipalities and/or regions joined The Covenant of Mayors (CoM), the initiative of the European Commission to sign a voluntary agreement to reach and exceed the goal of $20 \%$ reduction of $\mathrm{CO}_{2}$ emission by 2020 also at the local and/or regional level and to contribute 20-20-20 by 2020 climate and energy policy targets. Thus, a number of various local and regional 
activities specified in the sustainable energy action plans (SEAPs) is complementing the national policies and measures.

Energy policies at the regional level may result in long lasting effects and can successfully influence the energy performance of an urban system if we consider the whole built environment and focus on the energy renovation process in existing buildings [3]. The Kočevje region is one of the most naturally preserved areas of Slovenia and Central Europe. Forests cover more than $90 \%$ of the total area. The municipality started to work on sustainable energy policies systematically in 2008, when the local energy concept [4] was adopted. It includes a top-down analysis of existing conditions in the field of energy use and supply in different energy sectors (with emphasis on public buildings) and possibilities of use of local renewable energy sources (RES). In the local energy concept the EE and RES targets in the region are defined and the action plan agreed. In 2014 Kočevje signed the Covenant of Mayors and started to prepare the SEAP, aiming at a significant reduction of energy related $\mathrm{CO}_{2}$ emission.

Magyar et al. [5] stressed that one of the most important design tasks related to the establishment and operation of heat supply systems involves design heat demand of a required reliability level. In the urban area of the city of Kočevje, the prevailing way of building heating is district heating systems, powered by wooden biomass and fuel oil. Most of the individual houses in the suburban area use wood and fuel oil as energy source for heating. Municipality plans to replace oil as a fuel source powering the district heating system with innovative cogeneration system with wooden biomass gasification process to considerably lower the carbon footprint from building heating, to increase local energy self-supply, and to increase level of renewable energy sources in the national power grid. Energy renovation of the existing building stock is ongoing, supported by national and municipal incentives for housing and public buildings. Public buildings constitute a specific group of buildings that require a complex analysis from the energy point of view taking into consideration the extent of renovation, different typologies, and other parameters, that have a significant impact on energy performance [6]. EE and RES measures on demand and supply side are being implemented to support the goal to reach almost zero emissions in the Kočevje region.

Planning and monitoring of the impacts of a variety of policies and measures in the building sector has become a complex task, in particular due to the fragmentation of the building stock (in terms of shape, age, renovation status, ownership, and intended use) and several data gaps. In the literature review, Fabbri and Tarabusi [7] investigated and classified various top-down and bottom-up methodologies for buildings energy performance evaluation, with respect to extensive (e.g., city) or partial scale (i.e., district) and the (non-)aggregation of input data. The same paper also concluded that the term "top-down" suggests the idea of a "a bird's-eye view", while the term "bottom-up" refers to a "worm's-eye view", i.e., a view which includes a part of the object of study, evaluated in a detailed and accurate way. To support policy decisions, usually, the top-down building stock models are used [7], taking into account the (aggregated) statistical data on the floor area per year of construction of the building stock diversified per building type (i.e., residential houses and apartment buildings; buildings for non-residential use). The weakness of such models is that they disregard or only roughly consider the actual condition of the building stock, which is a result of the actual renovation dynamics, characterized by the information on the renovation done and on the basic technical details of the implemented works on building elements, energy systems, or on the building as a whole.

Salvia et al. [8] investigated the process of local and regional energy planning as well as available decision support tools and concluded that municipalities and regional authorities rarely use analytical tools to support the policy-making process and steer public administrators to adopt decision support tools for planning sustainable energy and climate strategies. The study recommends that energy planners and local and regional authorities all around Europe use a detailed model of the building stock as an important support tool when designing or assessing energy related strategies. To respond to this need, the research in this paper aims to develop a bottom-up model of the building stock in the geographical region by integrating publicly available databases and surveys, relevant for forecasting the impacts of climate and energy related policies and measures in the region. Specific structure of the 
bottom-up model will enable more detailed modelling of the building stock with periodic integration of new records in databases and thus improved accuracy of the model for tracking regional energy policy targets. The aim of the study is also to test the bottom-up model on the case study of Kočevje, to validate it and to forecast the impacts of sustainable energy policies in the region through dynamic modelling of energy performance of buildings.

Modelling energy use in buildings is an important step towards designing and implementing policy measures related to energy savings in buildings. Swan and Ugursal [9] reviewed available models for assessing the effects of energy saving measures (also referred to as energy efficiency measures, representing actions aimed at reducing energy demand in buildings) in the residential sector, and concluded that so-called bottom-up modelling of buildings is required to determine the impacts of new technologies. On the other hand, a bottom-up model of the building stock typically comprises building physics modelling for calculating the energy use of individual buildings, and extrapolation of the results to a region or a country [10].

Kavgic et al. [11] reviewed selected bottom-up building stock models for energy use in the residential sector and proposed that they should: (a) estimate the baseline energy demand of the existing building stock; (b) explore the technical and economic effects of different $\mathrm{CO}_{2}$ emission reduction strategies over time, including the impacts of new technologies; and (c) identify the effects of the strategies on the quality of the indoor environment.

Kovacic et al. [12] studied life-cycle based renovation strategies considering not only structural and thermal refurbishment, but also the social aspects of an ageing society needs. Galvin [13] analyzed the adequate combination of energy efficiency measures due to progressively higher energy renovation standards and argued the cost-effectiveness of German policies on subsidized thermal renovation of existing building stock.

In the framework of the Intelligent Energy Europe (IEE) project TABULA [14,15], a building typology of existing dwelling stock was developed using different types of buildings and periods of building construction in each country. Later on, the work on residential buildings typology was upgraded and new schemes of renovation monitoring as well as modelling of energy balance scenarios were developed in the scope of IEE EPISCOPE [16] project, which consists now of 20 European countries. When dealing with the bottom-up model, the typology approach is a good tool for determining the energy performance of buildings where no data on the current state of the building is available. Aelenei et al. [17] studied public buildings typology in selected countries to enable planning of cost optimal energy renovation towards the nationally defined nZEB energy indicators. More information on detailed data on reference non-residential buildings in selected EU countries can be found also in IEE RePublic_ZEB project [18].

In the frame of the EPISCOPE project the basic model of the building stock on a national level was developed, however it deals with residential buildings only. The presented model needs to be further extended with non-residential buildings and improved with the reference buildings from IEE RePublic_ZEB project in a way so that it enables adaptation of strategies that concern building stock of a different scale-single building, neighborhood, regional, or national levels.

The bottom-up model presented further in this paper intends to more accurately determine the status of the building stock in terms of energy performance characteristics. This shall be achieved by cross-linking publicly available databases on the building stock, national surveys on energy use in buildings, and records on implemented subsidized energy efficiency measures as well as the data on the structure of energy supply. The integration of EE and RES measures on the demand and supply side of the building stock shall be demonstrated in the case study by the application of the bottom-up model in the Kočevje region.

\section{Methodology}

In order to quantify the potential for renovation and determine the potential of efficiency to produce space heat and hot water, building stock models are used in most cases. Building stock 
characteristics must be known in order to estimate the impact of energy-efficiency measures on the stock. Using the bottom-up modelling approach, the dynamic simulation model extrapolated energy consumption based on the type of building, construction year, and energy carriers used at the regional and national levels and combined statistical calculation methods with technical and physical calculation methods. For the simulations of the building stock, several extensive databases were integrated into the model. The model covers the residential and non-residential building stock, based on Energy Performance Certificates (EPCs) per a particular building, where feasible or based on building typology. The modelling approach described in this chapter enables the simulation of all potential combinations of technical measures concerning the thermal insulation of the building envelope and improvements of technical systems. The development of buildings' energy projection is simulated in the form of scenarios.

\subsection{Data Sources}

Several data sources were used in the bottom-up model of the building stock in order to ensure sufficiently accurate and comprehensive analysis of dynamic energy balance of the building stock in the region:

- Databases from Geodetic Administration of the Republic of Slovenia-Register of Real Estates [19];

- Eco Fund, Slovenian Environmental Public Fund [20];

- National energy efficiency action plan 2014-2020 for Slovenia [1];

- Statistical Office of the Republic of Slovenia: provides data on the number and area of completed dwellings (new construction, extensions, conversion according to the CC-SI classification), the number of demolished dwellings and others [21];

- Intelligent Energy Europe projects TABULA [22], EPISCOPE [16], RePublic_ZEB [18];

- Register of Energy performance certificates [19];

- REUS, Survey of the energy efficiency in Slovenia [23].

The main sources for bottom-up modelling are the Register of Real Estates (REN) and the register of energy performance certificates (EPC register), both accessible at Geodetic Administration of the Republic of Slovenia (GURS), the database of Eco fund subsidies, and REUS survey (Figure 1). One of the biggest challenges is linking the energy performance related data of a particular building across all relevant databases, since each data source has been established separately throughout the past eight years since 2007. REN register, managed by GURS, keeps complete (actual) data on the renovation of thermal envelope components up to 2008 with minor updates up to 2014. Eco fund keeps data of conferred national subsidies for thermal envelope components and building systems from 2008 [20]. The EPC register was established in 2013 by the responsible ministry and linked into the database of GURS. It covers up to date (2015 status) 3\% of the building stock per building. EPC register stores the energy indicators and data on energy carriers per certified building. REUS survey is based on a poll that was conducted through interviews on the representative sample of 1006 households in Slovenia, regarding key areas of energy consumption in households and shows indicators on the status of the buildings and technical equipment of households as well as the building owners' intention of modernizing buildings and systems [23].

One of the main addressed challenges is to identify the renovation on a particular building, the exact extent of it and cross-check of the information from other sources to avoid duplication. Two basic cases of recorded renovation in Slovenian databases are illustrated by examples:

- A renovation can be recorded in Register of Real Estates, but the owner did not apply for a subsidy. The data on renovation is recorded in Register of Real Estates only.

- A renovation of the roof for a particular building was recorded in 2002 in Register of Real Estates and the owner received a subsidy for the replacement of the window and insulation of a roof 
in 2013. The overall process of renovation identification needs to identify the last recorded renovation of a building component from all data sources.

Upon the establishment of the status-quo of the building, renovation rates according to the total surface area are determined.

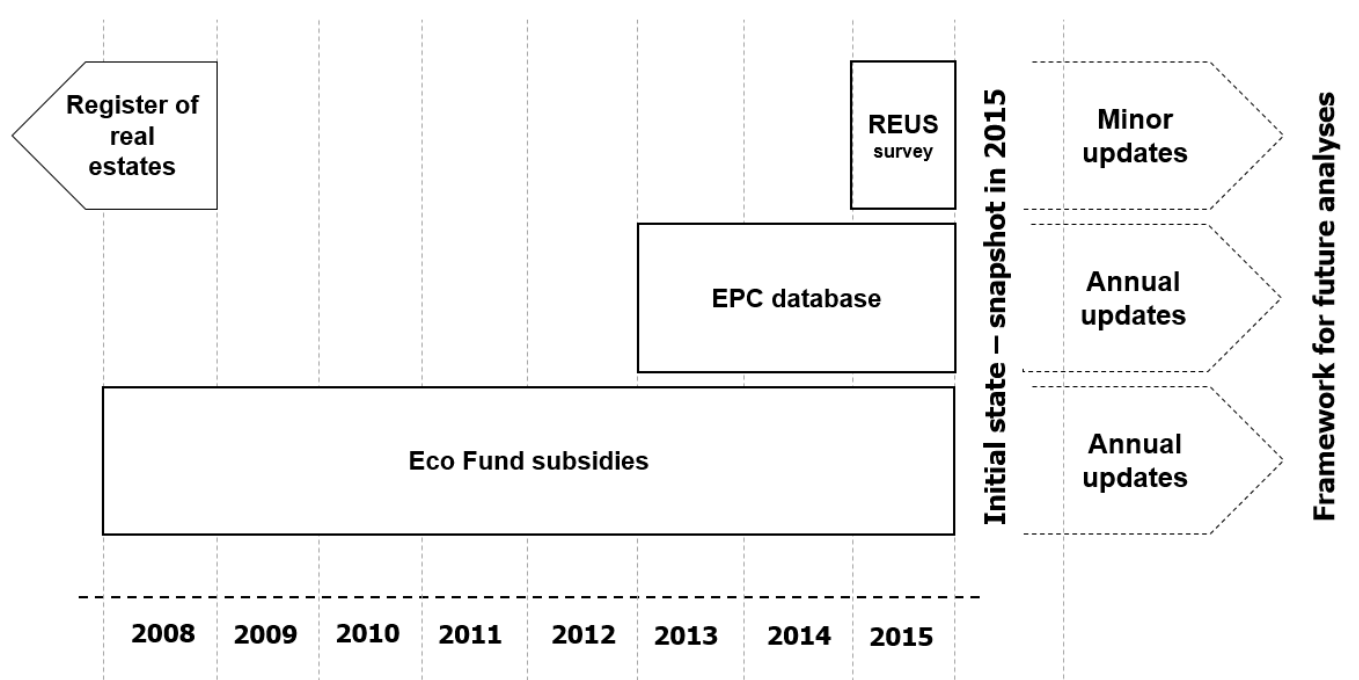

Figure 1. National data sources as framework for bottom-up modelling of the building stock's energy performance.

\subsection{Bottom-Up Model}

A bottom-up building stock model (BuilS) is a spatially-referenced, parameterized per-building model developed with the purpose of determining the energy performance of the building and further building the energy balance of the building stock. The presented model addresses two main challenges: (1) having a precise and open bottom-up building model that is continually improving with new information on buildings (e.g., REN, EPC register, and REUS); and (2) having a mathematical model that enables modelling of strategies of cities/regions/countries for building stock renovation and shifting towards sustainable energy supply.

The model uses "three layers" for calculation. The first layer is a long-term model of the building stock. It quantifies the expected future annual stock and reference floor area on the basis of the assumed past and future demand, i.e., the assumed development in persons, persons per dwelling and reference floor area per dwelling, potential for (partial/full/deep) renovation, based on the assumption for renovation and new built rates. This layer of the model also follows the ageing development of each type/age segment of the stock, with a predicted lifetime of building component and its technologies for heating and DHW after which the building qualifies for renovation based on the proposed scenarios of renovation rates for each age band (construction periods: 0-1945, 1946-1970, 1971-1980, 1981-2001, 2002-2008, 2009-to date). According to these scenarios, the model identifies the adequate number of buildings for renovation, depending on the initial state before renovation (concerning thermal envelope components and heating systems) (Figure 2).

The first layer of the model considers four different initial buildings states-unrefurbished, partial, full, and deep renovation (Figure 2). When considering possible renovation of buildings, different levels of renovation lead to the change of the initial state, e.g., a partly renovated building (roof renovated in 2008) can in the future be subject to full renovation (if renovation of a façade and boiler replacement are implemented) in order to reach the level of fully renovated building. The initial state of the building offers different potential for renovation, where four possible levels of the initial state are assumed: 


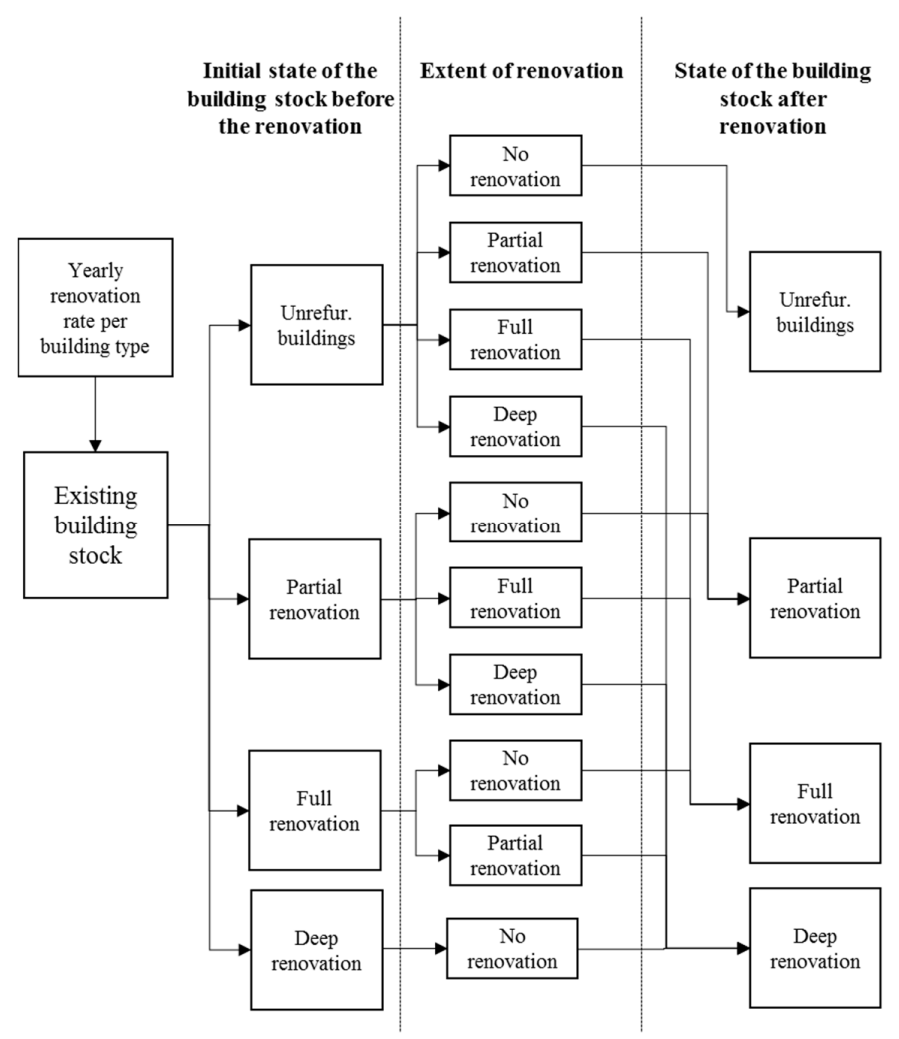

Figure 2. Process of modelling the energy renovation in the BuilS model (first and second layer).

- Unrefurbished: Based on the existing data, none of the building envelope components (façade, roof, or windows) or technical systems had undergone renovation in the past. Such a building is identified as unrefurbished and therefore has potential for renovation on all building envelope components and technical systems. Unrefurbished buildings can be subject to partial, full, and deep renovation, e.g., a building built in 1975 has not any undergone renovation works in the past, therefore has a potential for renovation of façade and roof and replacement of windows and technical systems for heating and domestic hot water (DHW).

- Partial Renovation: Based on the existing data, the building has undergone renovation on one or two building envelope components (façade, roof, or windows) in the past, therefore the building has the potential for renovation on one or two components of the thermal envelope and technical systems. Such a building is identified as partially renovated and can be subject of partial, full or deep renovation, e.g., a building built in 1975 had a renovated façade in 2000, therefore it has potential for renovation of the roof and replacement of windows and technical systems for heating and DHW.

- Full Renovation: Based on the existing data, buildings identified as fully renovated can be of two types.

The building has undergone renovation of two building envelope components and replacement of technical system for heating. Such a building has potential for renovation on only one building envelope component and can therefore be the subject of partial renovation, e.g., a building built in 1975 had a renovated façade in 2000, roof in 2005, and replaced boiler for heating and DHW in 2012, therefore it has a potential for renovation with the replacement of the windows and technical systems for heating and DHW.

- The building has undergone renovation of all three building envelope components, while the technical systems have not been replaced. Such a building has a potential for renovation only for the replacement of technical systems and can therefore be subject to partial renovation, 
e.g., a building built in 1975 had a renovated façade in 2000, roof in 2005, and replaced windows in 2012, therefore it has a potential for the replacement of technical systems for heating and DHW.

- Deep Renovation: the building has undergone major renovation works in the past, all building envelope components had been renovated, heating and DHW systems have been replaced and thus the building is considered to have a low energy demand for space heating [15]. Such buildings do not have any potential for renovation and are considered as deeply renovated.

In the BuilS model, one of the above initial states was attributed to each building in the case study, according to the available energy-related data on exact buildings in data sources described in Section 2.1. Renovation rate in the model is a weighted rate according to the renovation level (Figure 2) and expected energy savings, respectively. For the purpose of this work, the model adopts Slovenian national strategy renovation rates [2], i.e., maximum annual renovation rate in the building category is adopted from reference and intensive building renovation scenarios.

The second layer of the model is an energy and emission layer. The input data are the results from the first layer and additional data sources concerning heating systems and energy carriers in buildings. If the building is connected to a district heating network (identified through network plan) or the energy carrier for heating and domestic hot water is known from an EPC, the information is allocated to the particular building in the model. The rest of the building stock is assumed to be supplied by statistical distribution of energy carriers (Figure 3, [21,23]). In the model, the energy use of the building is either estimated on the basis of building typology, TABULA/EPISCOPE for residential and RePublic_ZEB for non-residential building $[16,18]$, or allocated from the EPC register, if an EPC is available for a particular building. The case study consists of 6880 residential and 204 non-residential buildings (Table 1); 131 among them have an EPC. The latter were submitted in 1.5 year period from the establishment of the national EPC register in mid-2013.

Table 1. Structure of the existing buildings in the case study of Kočevje, presented per building type, period of construction, and renovation level.

\begin{tabular}{|c|c|c|c|c|c|}
\hline $\begin{array}{l}\text { Period of } \\
\text { Construction }\end{array}$ & Level of Building & $\begin{array}{c}\text { Single Family } \\
\text { Building } \\
\text { Nr. (-) }\end{array}$ & $\begin{array}{c}\text { Terrace } \\
\text { Building } \\
\text { Nr. (-) }\end{array}$ & $\begin{array}{l}\text { Multi Family } \\
\text { Building } \\
\text { Nr. (-) }\end{array}$ & $\begin{array}{c}\text { Apartment } \\
\text { Block } \\
\text { Nr. (-) }\end{array}$ \\
\hline \multirow{4}{*}{ Up to 1945} & nonrefurbished & 516 & 147 & 171 & 226 \\
\hline & partial renovation & 125 & 61 & 62 & 58 \\
\hline & full renovation & 81 & 44 & 44 & 41 \\
\hline & deep renovation & 59 & 33 & 31 & 29 \\
\hline \multirow{4}{*}{ 1946-1970 } & nonrefurbished & 248 & 183 & 134 & 230 \\
\hline & partial renovation & 84 & 67 & 53 & 59 \\
\hline & full renovation & 61 & 47 & 36 & 41 \\
\hline & deep renovation & 43 & 34 & 28 & 29 \\
\hline \multirow{4}{*}{ 1971-1980 } & nonrefurbished & 154 & 132 & 148 & 158 \\
\hline & partial renovation & 73 & 77 & 51 & 50 \\
\hline & full renovation & 54 & 55 & 36 & 34 \\
\hline & deep renovation & 38 & 41 & 26 & 27 \\
\hline \multirow{4}{*}{ 1981-2001 } & nonrefurbished & 149 & 101 & 124 & 125 \\
\hline & partial renovation & 82 & 64 & 64 & 58 \\
\hline & full renovation & 59 & 44 & 44 & 40 \\
\hline & deep renovation & 44 & 34 & 32 & 30 \\
\hline \multirow{3}{*}{ 2002-2008 } & nonrefurbished & 61 & 80 & 84 & 49 \\
\hline & full renovation & 43 & 60 & 59 & 35 \\
\hline & deep renovation & 33 & 44 & 41 & 26 \\
\hline \multirow{3}{*}{ After 2009} & nonrefurbished & 83 & 78 & 53 & 59 \\
\hline & full renovation & 61 & 57 & 37 & 40 \\
\hline & deep renovation & 43 & 40 & 28 & 30 \\
\hline
\end{tabular}

The third layer takes into account scenarios for sustainable renovation of the building stock (at a local, regional, or national level), e.g., more intensive renovation rates in specific year due to increased incentives, or an increased share of building connected to district heating network due to network 
expansion in a city district. The basic scenarios of building stock renovation summarizes the activities deriving from national strategies, formed in the frame of NEEAP and LTS. The national documents deal with two scenarios of building stock renovation in the future in Slovenia-reference and intensive scenario. Both of them provide the renovation rates per building type. The NEEAP envisages the behavior of restructure of used technologies for heating and domestic hot water as well (Figure 3 shows the structure level of used technologies at the beginning of the observation period). Based on the determined status quo of each building - characteristics of thermal envelope and technologies-the building can, according to its potential for renovation, be renovated in the scope of the model in order to fulfill the required renovation rates. Furthermore, the model can adopt a local/regional strategy as well, since the analysis deals with a particular building and is able to take into account more/less intensive activities in certain part of the city/region, etc.

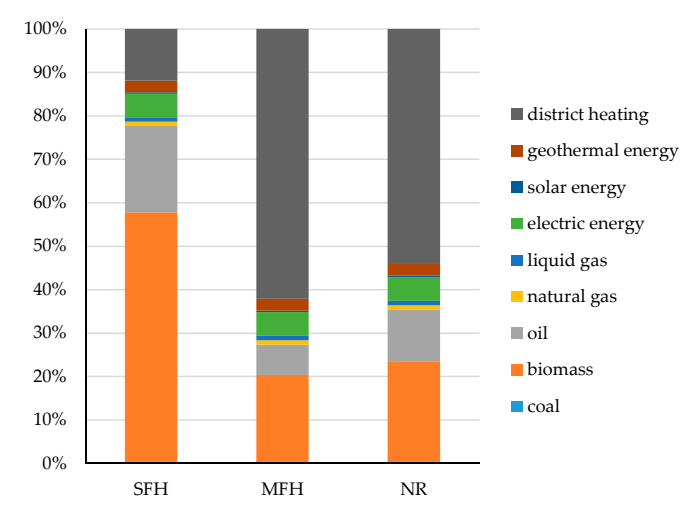

(a)

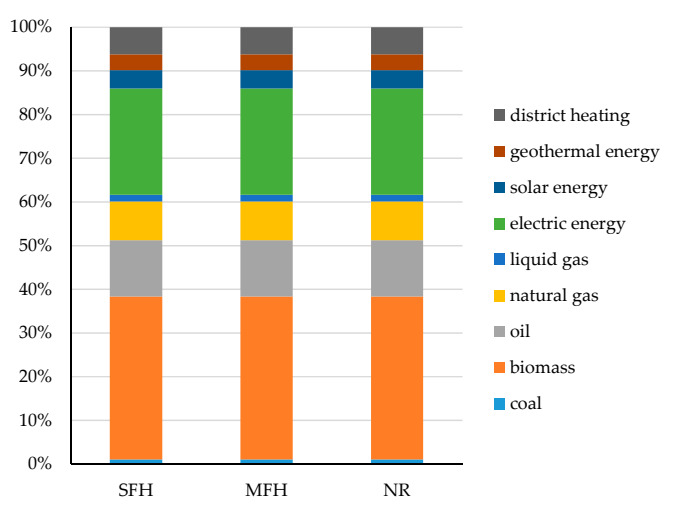

(b)

Figure 3. Share of used energy carriers for: (a) space heating, and (b) domestic hot water presented for single-family houses (SFH), multi-family houses (MFH) and non-residential buildings (NR).

\section{Results for the Kočevje Case Study}

The Kočevje region has an area of $555 \mathrm{~km}^{2}$ and a population of 16,500 inhabitants. The forests (including 217 ha of primeval forests) cover more than $90 \%$ of the total area. Since 2008, the authorities have systematically developed sustainable energy policies. LEK for Kočevje from 2008 states, that the annual emissions in the territory of Kočevje were estimated at 24,000 tons of $\mathrm{CO}_{2}$, not taking into account emissions from the electricity.

In the urban area of city of Kočevje, the prevailing way of building heating is district heating system, powered by wooden biomass and fuel oil. Most of the individual houses in the suburban area use wood and fuel oil as a heating source for heating. The municipality has an undergoing plan to replace oil fuel sources powering the district heating system with an innovative cogeneration system with wooden biomass gasification process to considerably lower the carbon footprint from building heating, to increase local energy self-supply, and to increase the level of renewable energy sources in national power grid.

\subsection{Modelling of Initial State}

The bottom-up model was applied to the Kočevje city region, which includes residential and non-residential buildings. The vast majority of past renovation rates of thermal envelope components were taken from two main sources-Register of Real Estates ([19], Table 2) and Eco fund subsides (Table 3). Weighted renovation rates according to useful surface area for case study is presented in Figure 4. The process of identification of buildings renovation is described in Section 2.2. 
Table 2. Share of recorded renovation measures on thermal envelope in the municipality of Kočevje by share of the total useful surface area of the building stock [19].

\begin{tabular}{cccc}
\hline & Walls & Roof & Windows \\
\hline 2000 & $0.59 \%$ & $1.59 \%$ & $1.10 \%$ \\
2001 & $0.54 \%$ & $1.19 \%$ & $0.64 \%$ \\
2002 & $0.71 \%$ & $1.06 \%$ & $0.95 \%$ \\
2003 & $0.96 \%$ & $1.56 \%$ & $0.78 \%$ \\
2004 & $1.30 \%$ & $0.94 \%$ & $1.30 \%$ \\
2005 & $1.52 \%$ & $1.14 \%$ & $1.37 \%$ \\
2006 & $1.71 \%$ & $1.70 \%$ & $1.72 \%$ \\
2007 & $0.53 \%$ & $0.39 \%$ & $0.34 \%$ \\
2008 & $0.63 \%$ & $0.20 \%$ & $0.42 \%$ \\
2009 & $0.15 \%$ & $0.11 \%$ & $0.00 \%$ \\
2010 & $0.64 \%$ & $0.22 \%$ & $0.24 \%$ \\
2011 & $0.54 \%$ & $0.15 \%$ & $0.00 \%$ \\
2012 & $0.91 \%$ & $0.10 \%$ & $0.11 \%$ \\
2013 & $0.02 \%$ & $0.00 \%$ & $0.02 \%$ \\
2014 & $0.00 \%$ & $0.00 \%$ & $0.00 \%$ \\
\hline
\end{tabular}

Table 3. Share of subsidized energy efficiency measures on thermal envelope in the municipality of Kočevje by share of the total useful surface area of the residential building stock [20].

\begin{tabular}{cccc}
\hline & Walls & Roof & Windows \\
\hline 2009 & $0.07 \%$ & $0.00 \%$ & $0.61 \%$ \\
2010 & $0.39 \%$ & $0.05 \%$ & $0.93 \%$ \\
2011 & $0.26 \%$ & $0.02 \%$ & $0.94 \%$ \\
2012 & $0.35 \%$ & $0.00 \%$ & $0.34 \%$ \\
2013 & $0.27 \%$ & $0.07 \%$ & $0.15 \%$ \\
2014 & $0.13 \%$ & $0.33 \%$ & $0.13 \%$ \\
\hline
\end{tabular}

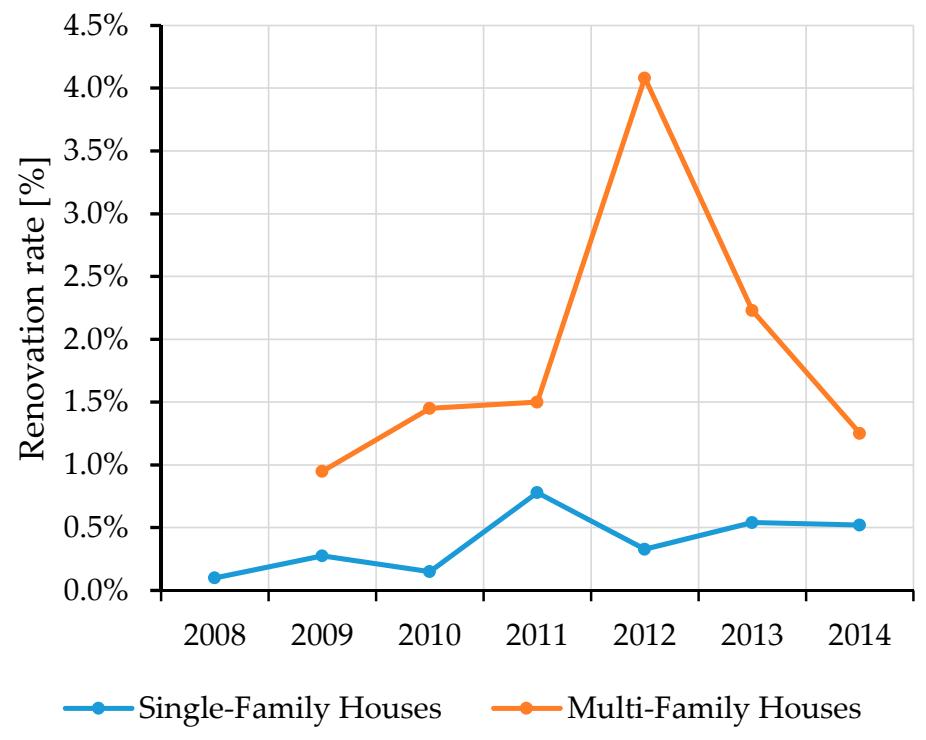

Figure 4. Renovation rate for single- and multi-family houses based on subsidized measures in municipality of Kočevje by share of the useful surface area.

For case study of Kočevje, the results show (Figure 5) the biggest potential for energy savings in the residential sector is for buildings built in the period 1946-1980. The analysis also shows that the majority of buildings built after 1980 have not been subject to any renovation yet and it is expected a considerable share will be subject to renovation in the near future, since the lifetime period of construction elements is 30 years. 


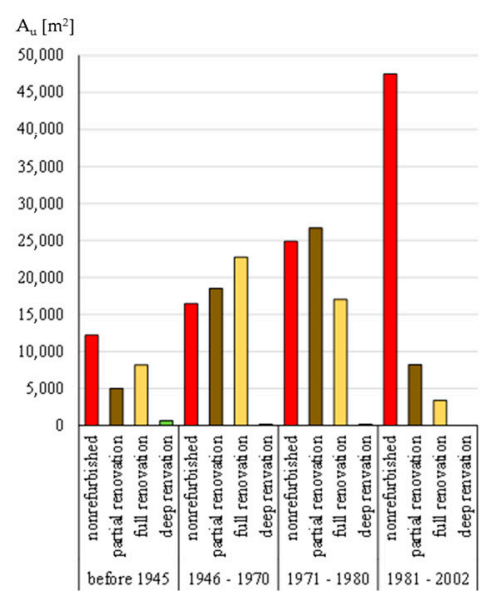

(a)

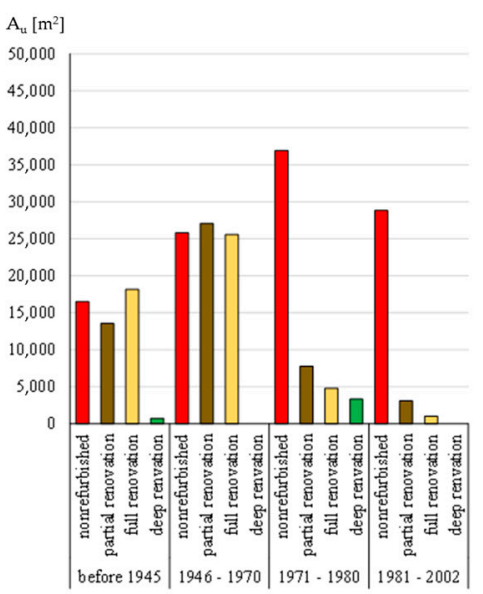

(b)

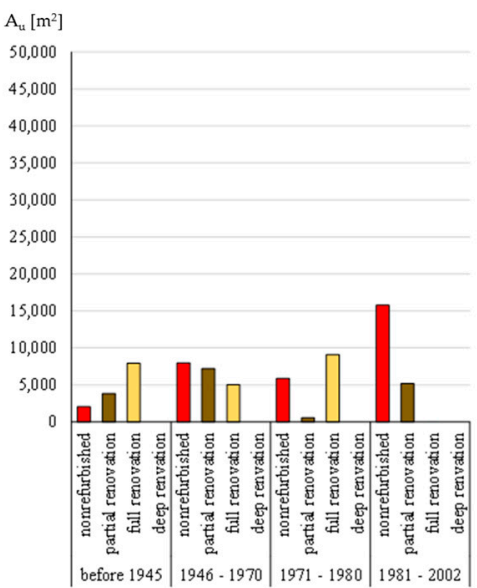

(c)

Figure 5. Initial potential for renovation for: (a) single-family houses; (b) multi-family houses; and (c) non-residential buildings in Kočevje with respect to total useful floor area $A_{u}$.

The initial potential for renovation of buildings in Kočevje is presented in Figure 5 with support of Geographic Information Systems (GIS) (Figure 6), which offers the opportunity to characterize building stocks in some systematic dimensions using geo-referenced information for buildings.

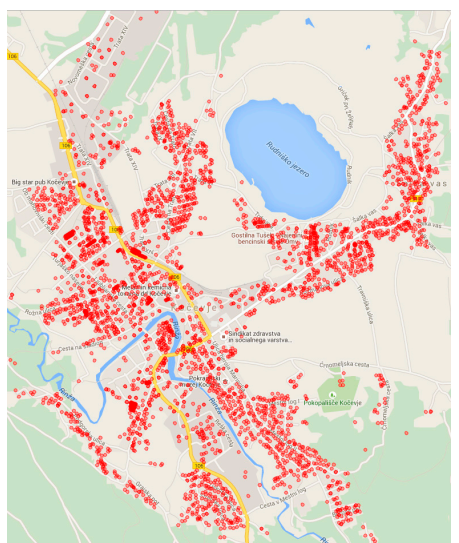

(a)

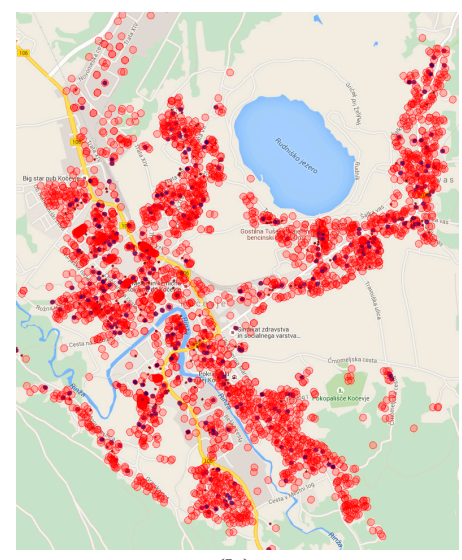

(b)

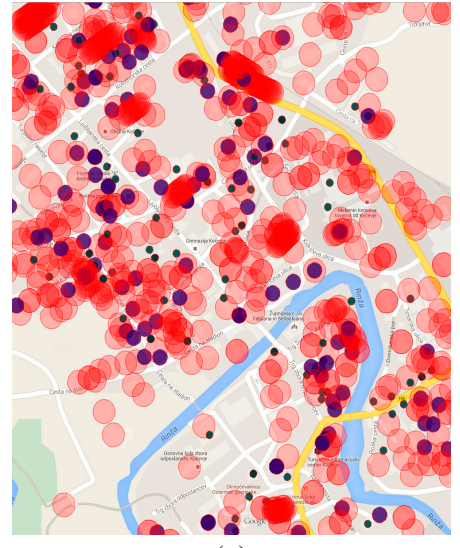

(c)

Figure 6. An overview of the current state of the building stock with GIS-based approach and Google Maps API: (a) all buildings in Kočevje; (b) buildings with potential for renovation on thermal envelope; (c) enhanced overview of the potential.

To this goal, an application with Google maps API, which enables a powerful way of presenting the energy balance of the building stock, was developed. Implemented in a case study of Kočevje, the application visualizes several aspects of the building stock, resulting from the analyses. Figure 6 shows the potential for renovation of the thermal envelope's components. The buildings where roof, façade, and windows have potential for renovation are marked as red with radius 3 . Buildings with two components for renovation have radius 2, and buildings with potential for renovation of only one component-radius 1 . The enhanced image reveals that the vast majority of the buildings have a big potential for renovation on their thermal envelopes. Furthermore, the model results were further integrated on a general map, where the ground floor of each building is seen. With an individual click on a building, the user is able to see the status quo of the building, concerning the energy characteristic of the building (age, past renovations, energy indicators). 


\subsection{Validation}

Well thought out validation is essential when describing the physical processes in buildings and dealing with the complexity of building energy modelling. Ideally, the performance of a building energy simulation tool (excel model, analysis software) should be validated against measured data from a real building. However, such data is not always available as urban indoor and outdoor environments are too complex to be instrumented sufficiently.

The differences between theoretical and actual energy consumption are considered to arise from a multitude of factors. Theoretical energy use in data sources is based on normalized conditions, based on a quasi steady-state method, such as indoor temperature of 20 degrees in the vast majority of buildings and heating degree days, as well as heating of the entire floor area. Infiltration rate is assumed on the basis of the characteristics of the construction elements, etc. The way that occupants use the building in reality probably differs from these assumptions. According to several authors [24-26], occupants' behavior and lifestyle is thought to be a key factor in the discrepancy between theoretical and actual heating energy use and is correlated to energy performance itself.

To this point, the BuilS bottom-up model was validated against the measured energy consumption of the buildings connected to the district heating network in Kočevje. In the period from 2008 to 2014, 196 buildings (residential and commercial) have or had been supplied by a local biomass district heating network in the city of Kočevje. The district heating network has gradually been expanding during this period, thus the number of connected buildings increased, while on the other hand, there had been some disconnections as well. A comparison of the normalized measured energy consumption and simulated energy use in the BuilS model for the observed period is presented in Figure 7. The objective was to observe if the predicted energy consumption for heating and domestic hot water falls within the range of accepted deviation.

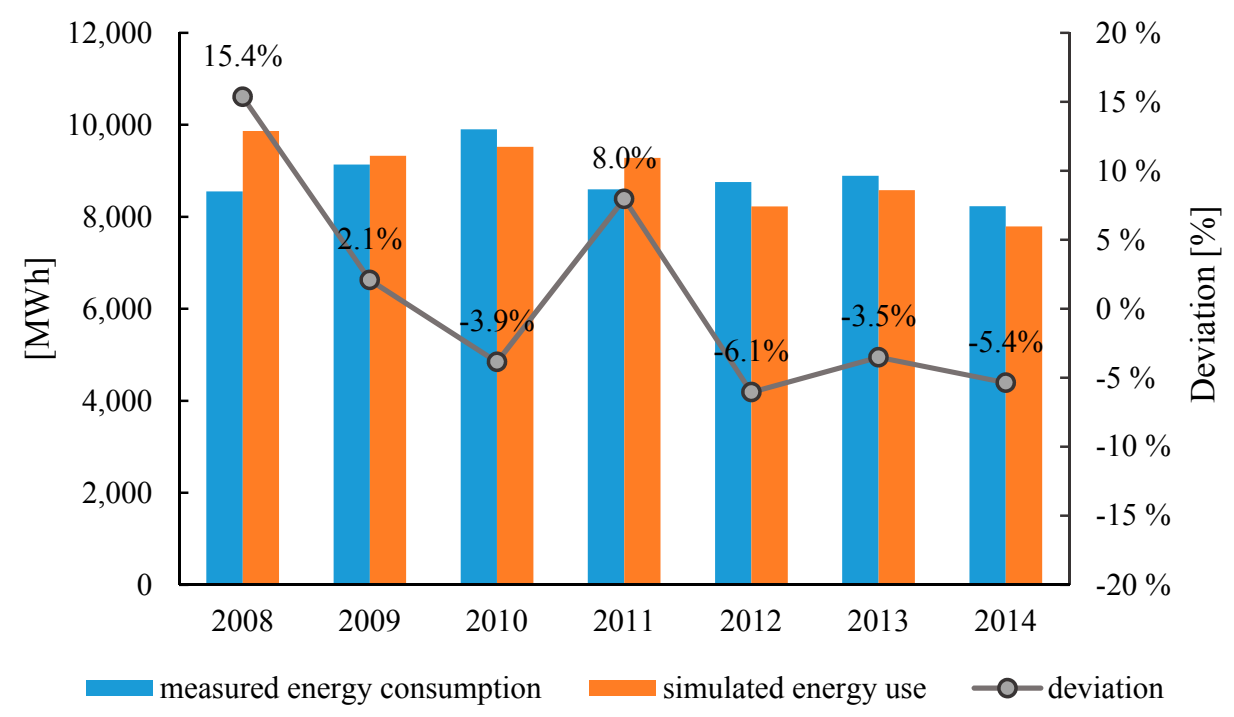

Figure 7. Comparison of the measured and modelled energy consumption of the case study Kočevje.

In the period between 2008-2014, the average deviation is 6.34\% (4.83\% in the period 2009-2014) which is below acceptable targeted $10 \%$ deviation. Only for the first year-2008-the deviation is higher $-15.4 \%$, the difference can be attributed to many factors. The key factor that must be taken into account for the first year only is the optimization of the local district heating substations. Performance in the first year of operation of the biomass district heating network might not be fully optimized yet, thus consumption was a bit higher. 


\subsection{Building Stock Renovation Scenarios}

In the scope of the presented paper, three scenarios, described in 2.2, were integrated into the BuilS model. Several parameters were varied in the scenarios in the period from 2015 to 2030, the most important ones being (in percentages):

- renovation rates (partial, full, and deep renovation)

- transition of technologies used for heating and domestic hot water

- share of building using the district heating network (deriving from municipal plans for the expansion).

The first two observed scenarios, reference and intensive scenario are taking into account as well the share of used technologies, which follows the national strategies and local state and limitations. Share of heat pumps and biomass boilers is slowly increasing, while share of energy carriers oil and liquid gas is decreasing. The third scenario strictly follows real local policy and is considered as an upgrade of a reference scenario, regarding the renovation rates on thermal envelope. From municipal plans for the expansion of biomass district heating network it was deducted which exact buildings in the future are going to be connected to the grid. This scenario presents a realistic applicability of the model on-site and demonstrates its potentials, e.g., measuring the effects of local policy on carbon footprint.

Key results are presented on Figures 8 and 9. In the base case of 2015, the estimated total final energy of the residential building stock in Municipality of Kočevje is $116.406 \mathrm{GWh} /$ year, with an emission factor of $0.232 \mathrm{~kg} \mathrm{CO}_{2} / \mathrm{kWh}$. This gives a specific total average energy need for heating of $161 \mathrm{kWh} / \mathrm{m}^{2} /$ year and a specific emission level of $37.4 \mathrm{~kg} \mathrm{CO} / \mathrm{m}^{2} /$ year.

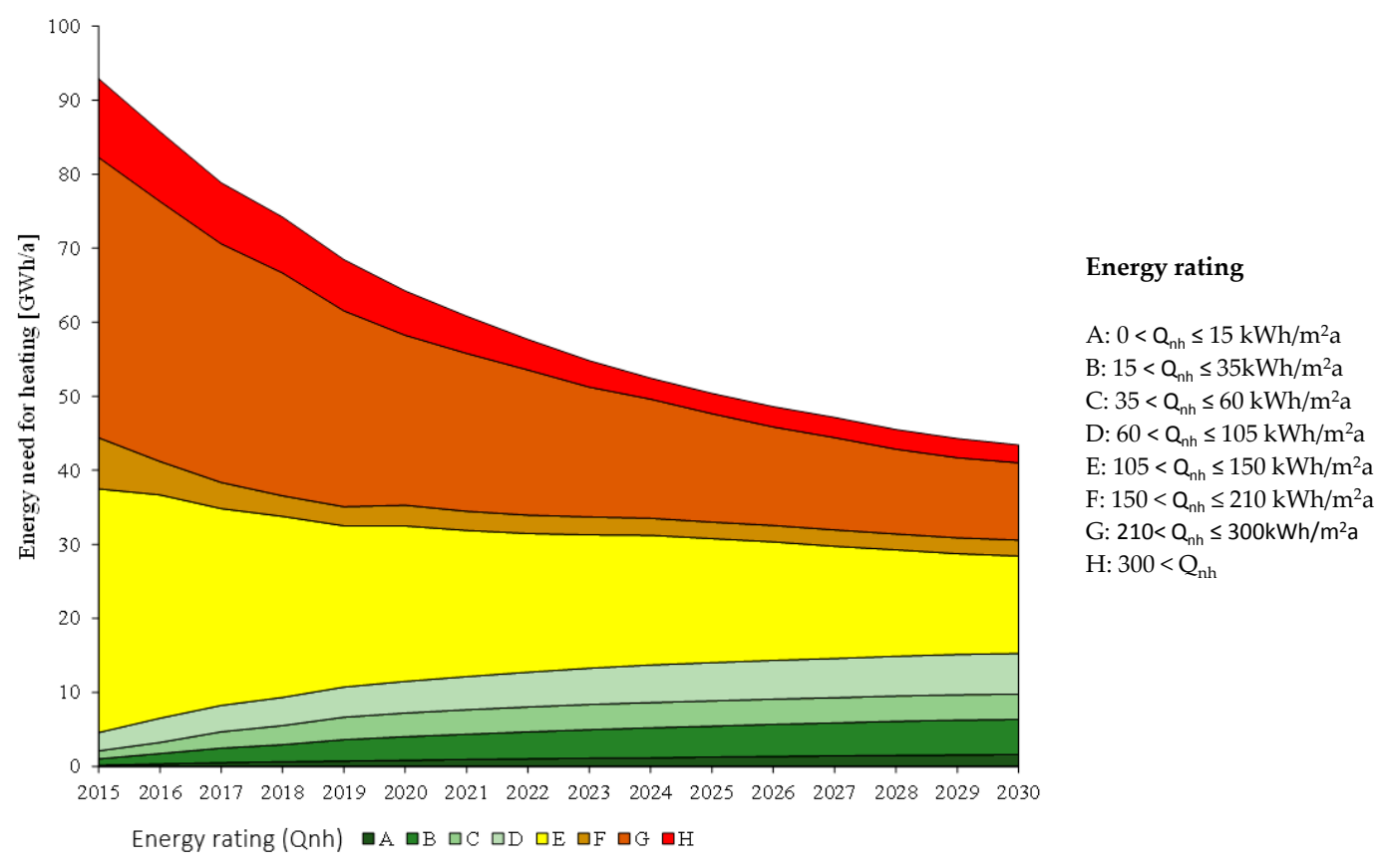

Figure 8. Case study of Kočevje: total energy need for heating of the building stock, presented per energy rating in national EPC.

The reference, intensive, and local policy scenarios give substantial reductions in annual total heat demand and $\mathrm{CO}_{2}$ emissions compared to 2015. The analysis reduction results are given with a range-from the reference scenario, which gives the lowest reduction, to intensive scenario, where the highest reduction of energy use and $\mathrm{CO}_{2}$ emission can be anticipated. The local policy scenario is an upgrade of the reference scenario, which means the reduction is in between both. The results 
present direct impacts that the municipality can expect after the implementation of a certain scenario, e.g., how much the total energy need is going to decrease and what $\mathrm{CO}_{2}$ emission reductions can be expected-a numerical result, by which the municipality can track if the plans follow their long-term plan according to SEAP or CoM.

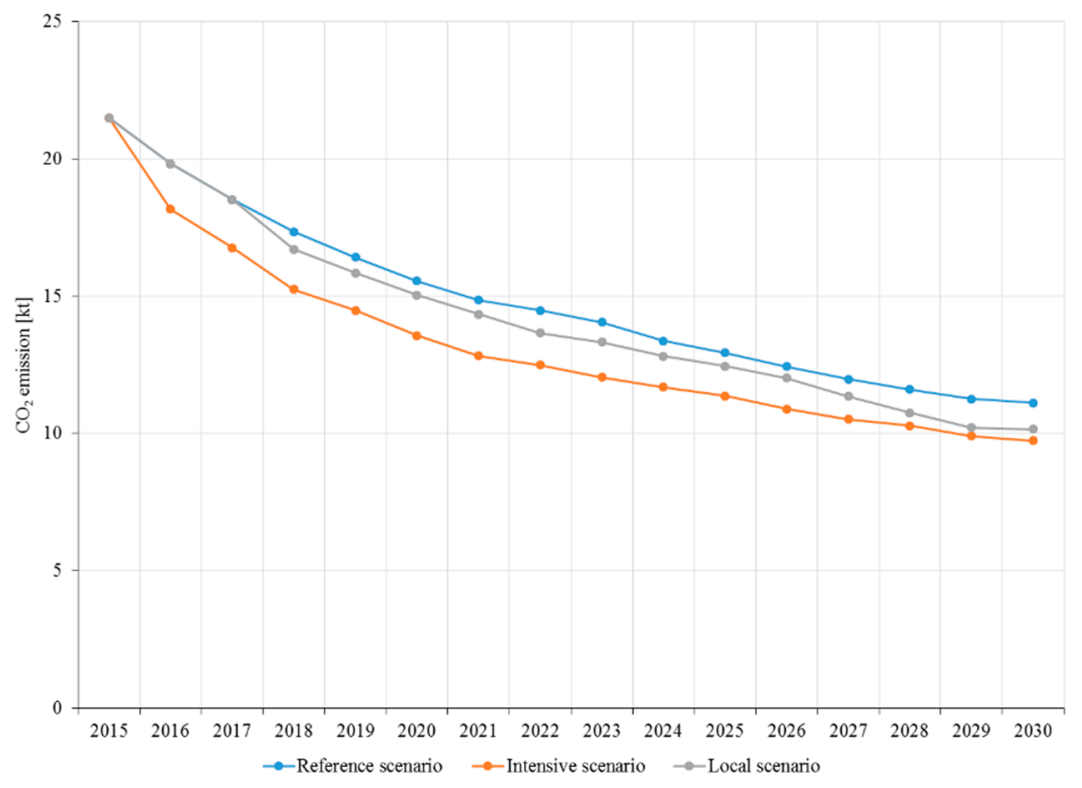

Figure 9. Carbon emissions for the building stock case study of Kočevje as calculated using BuilS model.

The total average energy needed for heating decreases from $161 \mathrm{kWh} / \mathrm{m}^{2} /$ year to a level of about $111 \mathrm{kWh} / \mathrm{m}^{2} /$ year in 2020, and to around $66 \mathrm{kWh} / \mathrm{m}^{2} /$ year in 2030 . With the given changes in the energy mix, and an overall $\mathrm{CO}_{2}$ emission factor increases from 0.232 to $0.258 \mathrm{~kg} \mathrm{CO}_{2} / \mathrm{kWh}$ in trend scenario, although considerable improvements are recorded in annual $\mathrm{CO}_{2}$ emissions. These are later reduced from $37.4 \mathrm{~kg} \mathrm{CO}_{2} / \mathrm{m}^{2} /$ year in 2015 to $26.3-26.8 \mathrm{~kg} \mathrm{CO}_{2} / \mathrm{m}^{2} /$ year in $2020,15.8-17.5 \mathrm{~kg}$ $\mathrm{CO}_{2} / \mathrm{m}^{2} /$ year in 2030 .

Despite the significant growth in building stock reference area by $16.1 \%$ from 2015 to 2030, these emission intensity improvements yield significant overall emission reductions (tons $\mathrm{CO}_{2}$ /year) of around $25 \%$ in 2020 and $46 \%-51 \%$ reductions in 2030, compared to the 2015 level, where buildings emit 18.567 tons of $\mathrm{CO}_{2}$ emissions (Figure 9). With respect to the estimation of carbon emissions in 2008 , the latter were reduced from 24,000 tons of $\mathrm{CO}_{2}$ /year to less than $19,000 \mathrm{CO}_{2}$ /year.

All the observed scenarios (reference, intensive, and local) show great promise in fulfilling the regional contribution to national goals for the reduction of final energy use and GHG emissions. According to policy targets and EPISCOPE benchmark levels (5\% reduction in 2020 and 30\% reduction in 2030 according to 2015) the goals are met in both the observed years-2020 and 2030. The primary energy is reduced in all scenarios. The EPISCOPE benchmarks are derived from a rough and straightforward translation of general EU climate protection targets: compared to 1990 the EU has decided on a $20 \%$ emission reduction until 2020 and a $40 \%$ reduction until 2030. An unofficially decided — but widely agreed-minimum climate protection target for industrial countries until 2050 is a reduction of $80 \%$ (again related to 1990) [27]. One of the focal points is the impact of the local energy policy implementation in practice, where the expansion of local district grid is considered in 2016, 2020, and 2025. Figure 9 shows the reduction of $\mathrm{CO}_{2}$ emissions in those years compared to the reference scenario, following the local scenario improvement. The modelled primary energy savings for the year 2030 are $14 \%$ (reference scenario), 33\% (local scenario), and 44\% (intensive scenario), respectively. 


\section{Discussion and Conclusions}

A bottom-up building stock model (BuilS) has been developed to identify building stock renovation potential considering energy performance of individual buildings through cross-linked data from various public available databases. The model enables integration of various EE and RES measures on the building stock to demonstrate long-term economic and environmental effects of different building stock refurbishment strategies. This makes it an appropriate optimization tool for designing renovation strategies and for exploration of their impacts on local, regional, and national climate and energy policy targets.

Identification of the renovation potential in the BuilS model is adjusted to the individual building stock, regardless of the geographical area, if building typology and corresponding energy related characteristics are available. For the BuilS model, the main data sources are the Register of Real Estates, the Register of energy performance certificates, the database of Eco fund subsidies, and the REUS survey. A common problem in the identification modelling step is a lack of relevant data on energy supply at a building level. In case of missing energy indicators, they can be derived either from IEE EPISCOPE building typology for residential buildings or IEE RePublic_ZEB for non-residential buildings.

In the presented case study, the BuilS model was applied to the Kočevje city area considering both residential and non-residential buildings. Results show that the biggest potential for energy savings in the residential sector is buildings built in the period 1946-1980 and that the majority of buildings built after 1980 have not been renovated yet.

The initial BuilS model of Kočevje was validated using the measured energy consumption of the buildings connected to the city district heating system. Using the extrapolation, the BuilS model results estimate final energy of the residential building stock in the Municipality of Kočevje to $116.406 \mathrm{GWh} /$ year, specific total average energy need for heating to $161 \mathrm{kWh} / \mathrm{m}^{2} /$ year and a specific emission level to $37.4 \mathrm{~kg} \mathrm{CO} / \mathrm{m}^{2} /$ year. The total average deviation between simulated and measured annual energy consumption in the observed period between 2008 and 2014 is $6.34 \%$. The validation results indicate that the BuilS model predicts the energy use well. Sunikka-Blank and Galvin [28] discovered that occupants in non-refurbished old buildings consume, on average, $30 \%$ less heating energy than calculated. This phenomenon is identified as the "prebound effect" and became more visible with the use of calculated energy indicators. In energy inefficient buildings, the occupants accept lower energy comfort in order to reduce the high costs for energy consumption. Once the building has undergone deep renovation, the opposite phenomenon can occur-the rebound effect. Occupants tend to consume more than calculated energy indicators due to improved thermal comfort. Although the validation results $(6.34 \%)$ are within the identified range of the prebound effect in the mentioned research, future work on the modelling should put more focus on the consideration of both the prebound and rebound effect.

After adequate validation, three strategies on how to approach to building stock renovation in Kočevje and their effects are presented with projections up to 2030. The BuilS model results estimate direct impacts that municipality can expect after the implementation of a certain strategy. Among the analyzed strategies, the primary energy savings until the year 2030 varies from $14 \%$ in the reference strategy to $44 \%$ in the intensive building stock refurbishment strategy. The $\mathrm{CO}_{2}$ emissions follow the energy savings and more sustainable structure of fuels for heating with a reduction of $25 \%$ in 2020 , which is beyond the $20 \%$ target from CoM, and $46 \%-51 \%$ reduction in 2030 compared to the year 2015 .

The potential of the Buils modelling of the building stock in tracking the regional targets on renewable energy sources utilization and progressive rehabilitation of the building stock was clearly demonstrated. The presented Kočevje case study shows that the BuilS bottom-up model enables us to set a correct baseline regarding energy use of the existing building stock and that such a model is a powerful tool for designing building stock renovation strategies and for evaluation of their impacts on climate, energy, and other policies aiming towards a low carbon society on all levels. 
The accuracy of the model depends on available information on local resources and local needs. The main shortcoming of available databases in Slovenia is the data integrity on energy efficiency at a building level and the lacking data on heating systems and energy carriers. Regular monitoring of the building stock through continually upgraded databases with new entries regarding building renovation on the level of each building, including energy performance certification of buildings and accelerated preparation of SEAPs under Covenant of Mayors, is therefore of utmost importance.

Acknowledgments: This work is based on the results of the European project IEE EPISCOPE (www.episcope.eu), partly financed by the European Commission within the European program "Intelligent Energy Europe" (IEE), under the coordination of the Institut Wohnen und Umwelt GmbH, Germany and project IEE RePublic_ZEB (www.republic.org), partly financed by the European Commission within the European program "Intelligent Energy Europe" (IEE), under the coordination of Italian Thermotechnical Committee Energy and Environment and it was partly developed in the frame of Research program P5-0398 (C) (2015-2018), financed by Slovenian Research Agency. The authors acknowledge the opportunity to exchange the experiences of national research internationally, in the frame of COST TU1104: Smart Energy Regions.

Author Contributions: Marjana Šijanec Zavrl, Gašper Stegnar and Henrik Gjerkeš defined research problem, Gašper Stegnar, Andraž Rakušček and Marjana Šijanec Zavrl conceived the methodology and designed the bottom-up model; Gašper Stegnar performed the modelling; Marjana Šijanec Zavrl and Gašper Stegnar validated the model on a case study; Gašper Stegnar, Henrik Gjerkeš and Marjana Šijanec Zavrl prepared results and discussion.

Conflicts of Interest: The authors declare no conflict of interest.

\section{References}

1. Republika Slovenija Ministrstvo za Infrastrukturo. Akcijski Načrt za Energetsko Učinkovitost za Obdobje 2014-2020 (AN URE 2020). National Energy Efficiency Action Plan in Slovenia for the Period 2014-2020. Available online: http://www.energetika-portal.si/fileadmin/dokumenti/publikacije/an_ure/an_ure_ 2020_sprejet_maj_2015.pdf (accessed on 21 July 2015).

2. Republika Slovenija Ministrstvo za Infrastrukturo. Dolgoročna Strategija za Spodbujanje Naložb v Energetsko Prenovo Nacionalnega Stavbnega Fonda. Long Term Strategy for Mobilizing Investments in Energy Renovation of Buildings. Available online: http://www.energetika-portal.si/dokumenti/strateskirazvojni-dokumenti/dolgorocna-strategija-za-spodbujanje-nalozb-energetske-prenove-stavb/ (accessed on 21 July 2015).

3. Republika Slovenija Ministrstvo za Infrastrukturo. Akcijski Načrt za Skoraj nič-Energijske Stavbe. National Plans for Increasing the Number of Nearly Zero-Energy Buildings. Available online: http://www.energetika-portal.si/dokumenti/strateski-razvojni-dokumenti/akcijski-nacrt-zaskoraj-nic-energijske-stavbe/ (accessed on 21 July 2015).

4. Local Energy Concept of the Municipality of Kočevje. Kočevje, Slovenia. Available online: www.kocevje.si (accessed on 15 September 2016).

5. Magyar, Z.; Garbai, L.; Jasper, A. Risk-based determination of heat demand for central and district heating by a probability theory approach. Energy Build. 2016, 110, 387-395. [CrossRef]

6. Caputo, P.; Costa, G.; Ferrari, S. A supporting method for defining energy strategies in the building sector at urban scale. Energy Policy 2013, 55, 261-270. [CrossRef]

7. Fabri, K.; Tarabusim, V. Top-down and bottom-up methodologies for energy building performance evaluation at meso-scale level-A literature review. J. Civ. Eng. Archit. Res. 2014, 1, 283-299.

8. Salvia, M.; Leo, D.S.; Pietrapertosa, F.; Cosmi, C. The role of analytical tools in supporting sustainable local and regional energy and climate policies. In Proceedings of the International Conference "Smart Energy Regions", Cardiff, UK, 11-12 February 2016; Patterson, J., Varriale, F., Eds.; The Welsh School of Architecture, Cardiff University: Wales, UK, 2016; pp. 242-252.

9. Swan, L.G.; Ugursal, V.I. Modeling of end-use energy consumption in the residential sector: A review of modeling techniques. Renew. Sustain. Energy Rev. 2009, 13, 1819-1835. [CrossRef]

10. Mata, E.; Kalagasidis, A.S.; Johnsson, F. A modelling strategy for energy, carbon, and cost assessments of building stocks. Energy Build. 2013, 56, 100-108. [CrossRef] 
11. Kavgic, M.; Mavrogianni, A.; Mumovic, D.; Summerfield, A.; Stevanovic, Z.; Djurovic-Petrovic, M. A review of bottom-up building stock models for energy consumption in the residential sector. Build. Environ. 2010, 45, 1683-1697. [CrossRef]

12. Kovacic, I.; Summer, M.; Achammer, C. Strategies of building stock renovation for ageing society. J. Clean. Prod. 2015, 88, 349-357. [CrossRef]

13. Galvin, R. Thermal upgrades of existing homes in Germany: the building code, subsidies, and economic efficiency. Energy Build. 2010, 42, 834-844. [CrossRef]

14. Loga, T.; Diefenbach, N.; Dascalaki, E.; Balaras, C.; Šijanec Zavrl, M.; Rakušček, A.; Corrado, V.; Corgnati, S.; Ballarini, I.; Renders, N.; et al. Application of Building Typologies for Modelling the Energy Balance of the Residential Building Stock; TABULA Thematic Report No. 2; Institut Wohnen und Umwelt GmbH: Darmstadt, Germany, 2012.

15. Šijanec Zavrl, M.; Rakušček, A.; Stegnar, G. Tipologija stavb Energetska Učinkovitost in Tipične Stavbe v Sloveniji. 2. Izdaja. Available online: http://episcope.eu/fileadmin/tabula/public/docs/brochure/SI_ TABULA_TypologyBrochure_ZRMK.pdf (accessed on 21 July 2015).

16. Episcope. Available online: http:/ / episcope.eu/ (accessed on 3 December 2015).

17. Aelenei, L.; Petran, H.; Tarrés, J.; Riva, G.; Ferreira, A.; Camelo, S.; Corrado, V.; Šijanec-Zavrl, M.; Stegnar, G.; Gonçalves, H.; et al. New Challenge of the Public Buildings: nZEB Findings from IEE RePublic_ZEB Project. Energy Procedia 2015, 78, 2016-2021. [CrossRef]

18. RePublic_ZEB. Available online: http://www.republiczeb.org (accessed on 3 December 2015).

19. Geodetska Uprava Republike Slovenije, Geodetic Administration of the Republic of Slovenia. Register Nepremičnin in Kataster Stavb. Register of Real Estates and Building Cadastre. Available online: http://prostor3.gov.si/javni/login.jsp?jezik=sl (accessed on 15 May 2015).

20. Annual Report on the Activities and Operations for Years 2009-2014, Ljubljana, Slovenia. Available online: http:/ / www2.ekosklad.si/ (accessed on 21 July 2015).

21. Statistični Urad Republike Slovenije. Ocena Gradnje Stavb. Available online: http://pxweb.stat.si/pxweb/ Database/Ekonomsko/19_gradbenistvo/05_19238_graditev_stavb/05_19238_graditev_stavb.asp (accessed on 21 July 2015).

22. Rakušček, A.; Šijanec Zavrl, M.; Stegnar, G. National Scientific Report-Slovenia. IEE TABULA—Typology Approach for Building Stock Energy Assess-Ment. Available online: http://episcope.eu/fileadmin/tabula/ public/docs/scientific/SI_TABULA_ScientificReport_ZRMK.pdf (accessed on 21 July 2015).

23. The Survey of Energy Efficiency Slovenia for the Housing Sector in 2015. Informa-Echo: Ljubljana, Slovenia. Available online: http://www.pozitivnaenergija.si/raziskava (accessed on 4 December 2015).

24. Gill, Z.; Tierney, M.; Pegg, I.; Allan, N. Low-energy dwellings: the contribution of behaviours to actual performance. Build. Res. Inf. 2010, 38, 491-508. [CrossRef]

25. Guerra Santin, O. Actual Energy Consumption in Dwellings: The Effect of Energy Performance Regulations and Occupant Behaviour; Ios Press: Amsterdam, The Netherlands, 2010.

26. Haas, R.; Auer, H.; Biermayr, P. The impact of consumer behaviour on residential energy demand for space heating. Energy Build. 1998, 27, 195-205. [CrossRef]

27. European Commission. Communication from the Commission to the European Parliament, the Council, the European Economic and Social Committee and the Committee of the Regions: A Roadmap for Moving to a Competitive Low Carbon Economy in 2050. Available online: http://eur-lex.europa.eu/ resource.html?uri=cellar:5db26ecc-ba4e-4de2-ae08-dba649109d18.0002.03/DOC_1\&format=PDF (accessed on 15 September 2016).

28. Sunikka-Blank, M.; Galvin, R. Introducing the prebound effect: The gap between performance and actual energy consumption. Build. Res. Inf. 2012, 40, 260-273. [CrossRef]

(C) 2016 by the authors; licensee MDPI, Basel, Switzerland. This article is an open access article distributed under the terms and conditions of the Creative Commons Attribution (CC-BY) license (http://creativecommons.org/licenses/by/4.0/). 